\title{
Peran Guru dalam Menanamkan Karakter Religius Peserta Didik Melalui Kegiatan Ekstrakurikuler Darus Keliling (Darling) di Madrasah Ibtidaiyah Negeri 3 Jember Tahun 2019
}

\author{
Ana Mar'atus Sholekhah \\ MI Sabilul Hidayah Banyuwangi \\ maratusana2@gmail.com
}

\begin{abstract}
Abstrak
Kegiatan keagamaan merupakan kegiatan yang amat penting di MI Negeri 3 Jember, mengingat masih banyak peserta didik yang membutuhkan bimbingan guru untuk memiliki karakter yang sesuai dengan tuntunan Islam, di zaman teknologi initidak bisa dipungkiri bahwa anak-anak zaman sekarang sudah mengenal yang namanya internet. Maka dari itu pendampingan orang tua dan guru sangat dibutuhkan dalam perkembangan anak-anaknya. Salah satu pendidikan yang diajarkan guru kepada peserta didiknya sejak dini adalah pengajaran tentang al-Qur'an.Oleh karena itu darus keliling (darling) merupakan kegiatan yang tepat dalam proses membelajarkan al-Qur'an dalam rangka menanamkan karakter religius kepada peserta didik. Fokus penelitian yang dikaji adalah: Bagaimana peran guru sebagai pembimbing dalam menanamkan karakter religius peserta didik melalui kegitan ekstrakurikuler darus keliling (darling) di MI Negeri 3 Jember tahun 2019? Penelitian ini memperoleh kesimpulan: Peran guru sebagai pembimbing dalam menanamkan karakter religius peserta didik melalui kegiatan ekstrakurikuler darus keliling di MI Negeri 3 Jember dalam hal ini adalah guru yang senantiasa membimbing anak-anak anggota darling untuk belajar al-Qur'an. Darling ini adalah sebuah wadah yang diberikan oleh guru untuk mengembangkan potensi peserta didik. Karakter religius pun terbentuk yakni sikap patuh dalam menjalankan agama Islam, misalnya membaca al-Qur'an. keliling di MI Negeri 3 Jember dalam hal ini menggunakan instrumen penilaian yang memiliki 3 aspek penilaian yakni aktif, kurang aktif dan tidak aktif.
\end{abstract}

Kata Kunci: Peran Guru; Karakter Religius; Ekstrakurikuler Darling (Darus Keliling) 


\section{PENDAHULUAN}

Madrasah Ibtidaiyah Negeri 3 Jember merupakan madrasah yang selalu berorientasi dalam mengembangkan kegiatan-kegiatan madrasah. Untuk mewujudkan visinya yaitu terwujudnya madrsah yang Islami, maka kegiatan keagamaan merupakan kegiatan yang amat penting di MI Negeri 3 Jember, mengingat masih banyak peserta didik yang membutuhkan bimbingan guru untuk memiliki karakter yang sesuai dengan tuntunan Islamdan yang paling penting adalah pembekalan al-Qur'an sejak dini kepada peserta didik, karena kita tahu bahwasanya pembekalan al-Qur'an sejak dini tersebut merupakan ilmu wajib yang harus diberikan guru kepada peserta didiknya di madrasah.

Zaman sekarang adalah zaman teknologi, mulai dari anak-anak hingga orang tua pasti sudah tidak asing lagi dengan yang namanya internet. Internet memiliki segudang manfaat jika kita bijak dalam menggunakanya, namun internet bisa juga berdampak negatif jika kita salah dalam menggunakanya. Apalagi jika kita berbicara internet pada anak-anak usia SD/MI, jika kita para orang tua ataupun guru tidak memberikan arahan yang baik untuk bijak dalam menggunakan internet atau media sosial, dikhawatirkan hal tersebut bisa mereka salah gunakan. Bisa jadi mereka menggunakanya pada hal-hal yang negatif dan bisa merusak generasi bangsa seperti kecanduan game online hingga pornografi. Mengingat pada saat ini teknologi informasi tumbuh dengan cepat tanpa batas melalui media internet. Hal tersebut menjadikan peserta didik terlalu sering interaksi dengan gadget, sehingga dia kehilangan kosentrasi belajar, sulit diarahkan, termasuk sulit untuk diajak beribadah.

Salah satu pendidikan yang diajarkan guru kepada peserta didiknya sejak dini adalah pengajaran tentang al-Qur'an. Oleh karena itu darling (darus keliling) merupakan kegiatanyang tepat dalam proses membelajarkan al-Qur'an dalam rangka menanamkan karakter religius kepada peserta didik. 
Darling juga kegiatan yang menyenangkan bagi peserta didik, karena proses pembelajaran tidak selalu di dalam kelas, tapi juga bisa di luar kelas. Bahkan darling tersebut juga bisa menambah keeratan silaturahmi bagi peserta didik maupun guru terhadap masyarakat.

Guru adalah salah satu komponen manusiawi dalam proses belajar mengajaryang ikut berperan dalam usaha pembentukan sumber daya manusia yang potensial di bidang pembangunan. Tugas dan peran guru tidaklah terbatas di dalam masyarakat, bahkan pada hakikatnya guru merupakan komponen strategis dalam menentukan gerak maju kehidupan bangsa. Dengan kata lain, potret dan wajah diri bangsa di masa depan tercermin dari potret berbanding lurus dengan citra para guru di tengahtengah masyarakat.Salah satu tugas seorang guru adalah membimbing, yang mana guru sebagai pembimbing adalah guru yang berkewajiban memberikan bantuan kepada peserta didik agar mereka mampu menemukan masalahnya sendiri, mengenal diri sendiri dan menyesuaikan diri dengan lingkunganya. Dalam dunia pendidikan, seorang guru tidak hanya menekankan pada kecerdasan intelektual namun juga kecerdasan spiritual. Di sinilah pentingnya pendidikan karakter religius bagi peserta didik. Sebab, karakter religius dapat mengembangkan diri agar tumbuh dan berkembang bersama nilai-nilai yang terkait erat dengan Tuhan Yang Mahakuasa, diri sendiri, serta sesama manusia.

Untuk mewujudkan karakter religius, MI Negeri 3 Jember menerapkan salah satu kegiatan ekstrakurikulernya yaitu Darus keliling (Darling) yang merupakan kegiatan membaca al-Qur'an secara bergantian atau bersama-sama dari rumah ke rumah yang dilakukan oleh peserta didik dengan bimbingan guru. Rumusan masalah dari penelitian ini adalah bahasan mengenai bagaimana peran guru sebagai pembimbing dalam menanamkan karakter religus peserta didik melalui kegiatan ekstrakurikuler darus keliling (darling) di MI Negeri 3 Jember. 


\section{METODE PENELITIAN}

Penelitian ini menggunakan pendekatan kualitatif.Sedangkan jenis penelitian yang digunakan adalah penelitian lapangan (field research) dengan jenis studi kasus. Dalam hal ini peneliti berangkat ke lapangan untuk mengadakan pengamatan tentang suatu keadaan atau masalah yang terjadi. Lokasi penelitian ini diambil di MI Negeri 3 Jember Kecamatan Sumbersari Kabupaten Jember. Penentuan informan dalam penelitian ini menggunakan metode purposive sampling. Dalam menentukan teknik pengumpulan data, peneliti menyesuaikan dengan jenis pendekatan yang digunakan, karena dalam penelitian ini menggunakan pendekatan kualitatif, maka teknik pengumpulan data yang digunakan yaitu wawancara, observasi dan dokumentasi. Dalam penelitian ini analisis yang digunakan adalah analisis model Mieles dan Huberman, yang menyebutkan bahwa analisis data ada tiga tahap yakni: Kondensasi, Display (Penyajian Data) serta kesimpulan. Keabsahan data merupakan salah satu langkah penting. Hal ini dilakukan untuk mengetahui tingkat kepercayaan yang dicapai dan menunjukkan kevalidan hasil temuan dengan jalan pembuktian oleh peneliti pada fakta yang akan diteliti. Pada penelitian yang dilakukan ini, peneliti menggunakan triangulasi teknik dan triangulasi sumber.

\section{HASIL DAN PEMBAHASAN}

Dalam penyajian data ini, peneliti kemukakan bahwa untuk memperoleh data digunakan metode wawancara, observasi serta dokumentasi dan hasilnya dapat dilihat sebagai berikut:

Sebagai seorang guru, sudah seyogyanya menjadikan murid-muridnya memiliki karakter yang baik, terutama karakter religius yang merupakan bentuk dalam mewujudkan generasi penerus bangsa yang berprestasi dan berakhlak. Seorang guru juga harus bisa membimbing peserta didik untuk dapat menemukan potensi yang dimiliki oleh setiap peserta didik juga 
membimbing apabila peserta didik tersebut mengalami kesulitan dalam hal belajar. Tidak hanya dalam kegiatan belajar mengajar di kelas, tetapi juga di luar kelas. Salah satunya adalah kegiatan darus keliling (darling).

Berdasarkan hasil wawancara dengan Bapak Anshori pada tanggal 16 April 2019 selaku koordinator darling yang menyatakan bahwasanya:

"Madrasah Ibtidaiyah Negeri 3 Jember menjadikan darus keliling (darling) sebagai salah satu kegiatan program ekstrakurikuler, yang bertujuan untuk memberikan wadah bagi peserta didik yang sudah mahir membaca al-Qur'an ataupun pemula yang masih belajar alQur'an. Yang artinya guru siap membimbing untuk peserta didik yang dalam taraf belajar al-Qur'an ataupun untuk peserta didik yang sudah lancar membaca al-Qur'an.”

Selain Bapak Ansori, peneliti juga melakukan wawancara pada tanggal 15 April 2019 dengan Kepala Madrasah Ibtidaiyah Negari 3 Jember yang menyatakan bahwasanya:

“Kegiatan darus keliling (darling) ini diharapkan para peserta darling mampu mencapai keutamaan-keutamaan dari membaca, mendengarkan serta mudah menghafalkan lafadz-lafadz al-Qur'an dengan baik dan benar, dengan bimbingan dari para guru yang senantiasa membenarkan jika ada bacaan al-Qur'an yang kurang benar. Darling ini juga sambil belajar mengenai tajwid serta makhorijul huruf, agar mereka paham bagaimana membaca al-Qur'an dengan baik dan benar. Tidak hanya guru yang membenarkan bacaan al-Qur'an yang mungkin salah ketika dibaca, namun juga peserta darus yang lain ikut membenarkan jika teman mereka salah dalam membaca al-Qur'an. Kegiatan darling ini juga bertujuan untuk melatih anak-anak membaca al-Qur'an secara berulang-ulang, bahwa ilmu dapat bertambah dan semakin kuat jika diamalkan serta menumbuhkan sikap istiqomah dalam mengerjakan kegiatan pembiasaan membaca al-Qur'an. Jadi yang paling utama adalah penanaman karakter religius yang berhubungan langsung dengan Allah karena membaca al-Qur'an merupakan perintah Allah SWT."

Peneliti juga melakukan wawancara dengan ke 30 peserta darus keliling pada tanggal 25 April 2019 yang mana rata-rata dari mereka menjawab pertanyaan dari peneliti dengan jawaban yang sama, berikut hasilnya: 
"Saya suka ikut darling, karena saya suka membaca al-Qur'an, selain itu saya juga bisa bertemu sama teman-teman yang berbeda kelas. bapak/ibu guru juga dengan baik dan sabar mengajari kami sampai bisa membaca al-Qur'an dengan tajwid yang benar."

Berdasarkan hasil interview dengan beberapa narasumber di atas dapat disimpulkan bahwasanya sebagai seorang guru, haruslah menjadi teladan kepada peserta didiknya, selain itu juga memberikan semangat untuk terus berprestasi, dan dalam proses nya tidak lupa guru juga harus menjadi pembimbing yang telaten dan sabar. Agar terbentuklah peserta didik yang cerdas dan memiliki karakter yang baik. Salah satunya adalah karakter religius yang memang sangat diunggulkan di MI Negeri 3 Jember, dengan adanya darus keliling (darling) ini peran guru sebagai pembimbing dalam menanamkan karakter religius peserta didiknya sudah sangat baik dilaksanakan.

Selain wawancara, untuk memperkuat data, peneliti juga melakukan observasi. Observasi dilaksanakan di rumah Ibu Khidir yang berada di desa Wirolegi Kecamatan Sumbersari pada hari Minggu, 28 April 2019 mulai pukul 07.00 - 09.00 WIB. Berikut hasil observasi yang peneliti peroleh.

Kegiatan darus keliling (darling) diawali dengan membaca do'a sebelum belajar, bacaan tersebut dibaca secara bersama-sama, kemudian membaca secara bergantian sedang yang lainya menyimak dengan didampingi oleh para guru. Setiap anak tidak diwajibkan untuk membaca alQur'an dengan suara yang lantang dan berirama, tetapi membacanya harus dengan tartil dan benar. Para peserta darling juga harus memperhatikan etika dan sopan santun ketika membaca ayat-ayat suci al-Qur'an. Dan di sinilah peran seorang guru untuk terus membimbing serta mendampingi para peserta darling. Setelah pembacaan al-Qur'an selesai semua, dilanjutkan dengan kultum oleh Pak Anshori selaku koordinator darling, dan untuk penutupnya adalah makan secara bersama-sama. 
Beberapa pendapat tersebut didukung oleh dokumentasi saat kegiatan darus keliling (darling) sebagai berikut.

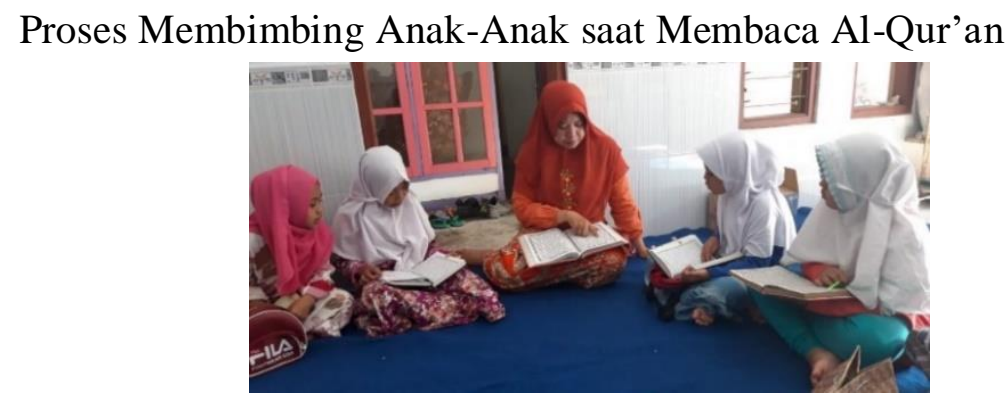

Sumber: Dokumentasi guru saat membimbing anak-anak darus keliling (darling)

Pada bagian ini akan membahas tentang keterkaitan antara data yang telah ditemukan di lapangan dengan teori yang relevan. Adapun pembahasan temuan sebagai berikut:

Darus keliling (darling) adalah kegiatan tindak lanjut dari pembacaan al-Qur'an. Dalam teori, kata "darus" tidak ada, yang ada yaitu tadarus yang bemakna membaca al-Qur'an sebagai bentuk peribadatan yang dapat mendekatkan diri kepada Allah SWT, dapat meningkatkan keimanan dan ketaqwaan yang berimplikasi pada sikap dan prilaku positif dan istiqomah dalam beribadah.Jadi, darling (darus keliling)/tadarus keliling adalah kegiatan membaca al-Qur'an secara bergantian atau bersama-sama yang dilakukan oleh peserta didik dengan bimbingan guru-gurunya.

Guru sebagai pembimbing memiliki kewajiban memberikan bantuan terhadap peserta didik dalam hal mengatasi kesulitan-kesulitan pribadi, kesulitan pendidikan, kesulitan memilih pekerjaan, kesulitan dalam hubungan sosial, dan interpersonal. Darus keliling (darling) diadakan sebagai upaya kegiatan seorang guru untuk membimbing para peserta didik dalam mempelajari al-Qur'an. Dalam teori, guru sebagai pembimbing memiliki peran dalam hal mengatasi kesulitan pribadi. Maksut kesulitan pribadi di sini adalah guru terus membimbing peserta didik yang masih kesulitan dalam membaca al-Qur'an. Selain itu, guru sebagai pembimbing 
juga berperan mengatasi kesulitan dalam hubungan sosial peserta didik. Darus keliling (darling) hadir sebagai program yang selain belajar tentang al-Qur'an, juga sebagai mempererat tali silaturahmi antara guru maupun peserta didik terhadap masayarakat. Jika dikaitkan dengan materi maka peran guru sebagai pembimbing dalam mengatasi kesulitan dalam hubungan sosial peserta didik sudah terlaksana, karena dalam kegiatan darling, para anggota darling bisa berhubungan langsung dengan teman-teman sebayanya maupun masyarakat dan yang paling penting adalah mempererat tali silaturahmi.

Madrasah Ibtidaiyah Negeri 3 Jember selalu berupaya mengedepankan madrasah yang Islami. Hal ini dibuktikan dengan banyaknya kegiatan keagamaan yang ada dan bertujuan untuk menjadikan karakter para peserta didik yang islami/religius. Salah satunya adalah kegiatan darus keliling (darling). Karakter religius adalah sikap dan prilaku yang patuh dalam melaksanakan ajaran agama yang dianutnya, toleran terhadap pelaksanaan ibadah agama lain dan hidup rukun dengan pemeluk agama lain. Jika dikaitkan dengan teori yang ada, maka darling ini bisa membentuk karakter religius peserta didik (anggota darling). Misalnya sikap dan patuh dalam menjalankan ajaran agama yang dianutnya. Hal ini dibuktikan dengan pembacaan ayat suci al-Qur'an. Membaca al-Qur'an merupakan salah satu ibadah untuk kita menjalankan perintah Allah.

Apabila seseorang mempunyai karakter yang baik terkait dengan Tuhan Yang Mahakuasa, seluruh kehidupanya pun akan menjadi baik. Namun, sayang sekali karakter yang semacam ini tidak selalu terbangun dalam diri orang-orang yang beragama. Hal ini bisa terjadi karena kurangnya kesadaran dalam keberagamanya. Oleh karena itu, anak didik harus dikembangkan karakternya agar benar-benar berkeyakinan, bersikap, berkata-kata dan berprilaku sesuai dengan ajaran agama yang dianutnya. Untuk melakukan hal ini, sudah tentu dibutuhkan pendidik atau guru-guru yang bisa juga menjadi teladan. Bukan guru (atau orang tua) yang 
mengajarkan kepada anak didik agar taat dan patuh serta menjalankan ajaran dari Tuhan Yang Mahakuasa, sementara ia sendiri tidak taat dan patuh. Sungguh, dalam hal ini anak didik membutuhkan contoh, figur dan keteladanan.

Pendidikan tidak hanya menekankan pada kecerdasan intelektual namun juga kecerdasan spiritual. Di sinilah pentingnya pendidikan karakter religius bagi peserta didik. Sebab, karakter religius dapat mengembangkan diri agar tumbuh dan berkembang bersama nilai-nilai yang terkait erat dengan Tuhan Yang Mahakuasa, diri sendiri, serta sesama manusia.

\section{KESIMPULAN}

Berdasarkan hasil analisis data-data yang diperoleh dari lapangan penelitian terkait peran guru sebagai pembimbing dalam menanamkan karakter religius peserta didik melalui kegiatan darus keliling (darling) di Madrasah Ibtidaiyah Negeri 3 Jember, maka diperoleh kesimpulan yaitu peran guru sebagai pembimbing dalam menanamkan karakter religius peserta didik melalui kegiatan darus keliling (darling) di MI Negeri 3 Jember dalam hal ini adalah guru yang senantiasa membimbing anak-anak anggota darling untuk belajar al-Qur'an. Yang mana darling ini adalah sebuah wadah yang diberikan oleh guru untuk mengembangkan potensi peserta didik. Karakter religius pun terbentuk yakni sikap patuh dalam menjalankan agama Islam, misalnya membaca al-Qur'an.

\section{Daftrar Pustaka}

Azzet, Akhmad Muhaimin. 2011. Urgensi Pendidikan Karakter di Indonesia, Jogjakarta: Ar-Ruzz Media, 2011.

A.M, Sardiman. Interaksi dan Motivasi Belajar Mengajar, Jakarta: Rajawali Pers, 2016.

Hamalik, Oemar. Proses Belajar Mengajar, Jakarta: PT Bumi Aksara, 2011. 
Listyarti, Retno. Pendidikan Karakter dalam Metode Aktif, Inovatif dan Kreatif, Jakarta: Erlangga, 2012.

Sahlan, Asmaun. Mewujudkan Budaya Religius di Sekolah Upaya Mengembangankan PAI dari Teori Ke Aksi, Malang: UIN Maliki Press. 2010.

Thabrani, Abd. Muis. Pengantar dan Dimensi-Dimensi Pendidikan, Jember: STAIN Jember Press, 2013.

Usman, Moh Uzer. Menjadi Guru Profesional. Bandung: PT Remaja Rosdakarya, 2016.

Anshori, wawancara, Jember, 16 April 2019.

Didik Mardianto, wawancara, Jember 15 April 2019.

Silva dkk, Wawancara, Jember 25 April 2019.

Observasi, Jember, 28 April 2019 